\title{
Sustainability in Accommodation Service Industry: The Role of Quality and Value
}

\author{
Tintin Suhaeni ${ }^{1, \mathrm{a}}$, Adila Sosianika $^{1}$ \\ ${ }^{I}$ Department of Business Administration, Politeknik Negeri Bandung, Bandung, Indonesia
}

\begin{abstract}
Hotel industry as a provider of tourist accommodation is an essential pillar of the tourism industry. This study is designed to identify how non-star budget accommodation industry sustain its business, through providing service that enables to satisfy and make loyal their customers. Referring to the existing literature, three predictors included in the model of developing guest loyalty, i.e. service quality, service value, and customer satisfaction. Data were collected from 298 domestic tourists in five tourism destinations in West Java; there are Cianjur, Cirebon, Bandung, Sukabumi, and Ciamis. The findings indicate that tourists tend not loyal to budget accommodation because of the service quality that they received does not meet their expectations. Similarly, tourists' perception on the perceived value and level of satisfaction are not as customer expected. In terms of how domestic tourist develop loyalty, the result confirms that service quality and perceived value are important determinants of tourist satisfaction and loyalty. Thus, it is suggested that creating a high service quality and value are imperative for the non-star hotel industry to develop its sustainable business.
\end{abstract}

\section{Introduction}

Literature $[1,2]$ concludes that accommodation service availability that suitable for tourist needs can give a positive impact on tourists intention to revisit a tourist destination. To meet the tourist expectation, hotels should provide a high quality of service that at least matched with their expectation in order they revisit to the same hotel for the next trip and attract more tourists to come. One of the main factors to develop such a quality service is by employing competent and loyal employees $[3,4]$.

There are many types of the hotel to cater the customer needs of accommodation services with broadly can be classified into hotels with star-rating and non-star-rating or budget hotel. Based on the number of employees, capital, and its sales turnover, non-starrating hotels can be categorized into small-medium enterprises. Like other small-medium enterprises, limited human resource and capital make these non-star hotels difficult in providing excellent service to the customers [5]. Meanwhile, star-rating hotels which do not face those problems tend to be able to provide a high-quality service and delivering program to create guest loyalty. On the other hand, statistical data [6] shows that tourists who stay in star-rating hotels are less than the number of tourist in non-star-rating hotels, 22,6 million compared to 37,6 million. Further, the data indicates that $75 \%$ tourists who

\footnotetext{
${ }^{a}$ Corresponding author : tintin.suhaeni@polban.ac.id
} 
stay in non-star-rating hotels are domestic tourists. Therefore, domestic tourists are the potential market for non-star hotels.

Due to the high potential of Indonesian tourism and a large number of domestic tourists, the development of non-star hotels should be an important issue for the hotel industry. This research is intended to explore guest satisfaction and guest loyalty as a sustainable business strategy for non-star hotel.

\section{Literature review}

\subsection{Concept of loyalty}

Arguably, having satisfied and loyal customer is one of the most fundamental issues for flourishing and sustaining the business, including in the accommodation industry [7]. Customer loyalty concept has been developed and tested by many researchers in the various industry context. Oliver [8] defines loyalty as a psychological commitment to keep buying the same product or services in the future, even though there is a persuasion from another competitor to switch buying their products. This definition emphasizes that the proper attitude towards a product or service not only driving customers to rebuy in the future but also make customers resistance to the competitors marketing efforts [9].

There are three aspects of customer intention to be loyal: cognitive, affective, and conative. Cognitive refers to customer trust and knowledge regarding a phenomenon [10]. Scholars [11] define cognitive loyalty as customer attitude towards a product or service based on their trust and knowledge about a product being preferred than competitor product. Affective loyalty is defined as a liking based on satisfaction. Scholars [8] maintain that loyalty is built based on affection concept, meaning that the whole of customer evaluation towards a brand consist of involvement, liking, and caring. Those factors occur because of satisfaction in using a product or service. Conative loyalty or behavioral intention is a loyalty state that triggers a commitment to buy something that appears first. Commitment to purchase a product will be influenced by customer preference to the product. As a consequence, having customers who commit is very important for every business and become a key for its sustainability, because they will be resistant to competitor promotion. Scholars $[2,12]$ report that commitment will differentiate customer who keep buying the product with loyalty and who is not.

\subsection{Loyalty determinant factors}

Literature has widely recognized that the main driver of loyalty is not only service quality but also value and satisfaction with the product or service. The quality of service refers to customer opinion about the superiority of service as a whole [13]. Past studies have verified the association between quality and satisfaction, value, and loyalty $[2,12,14]$. Basically, scholars have agreed that quality of service is a critical factor that influences on customer perceived service value, level of satisfaction, and customer favorable behavior. Perceived service value is a customer evaluation towards something that they receive based on what they already give [15]. Many studies have been conducted to analyses service value because of its favorable effect on both of customers and employees. Most of the researchers confirm a positive effect of service value towards the satisfaction level and loyalty behavior. Customer satisfaction is a significant factor that will influence to customer purchasing behavior, profit rate, and company stock value. The recent studies, using multivariate models, have analyzed and reported the positive consequences of satisfaction on customer loyalty behavior $[16,17]$. 


\subsection{Loyalty in accommodation industry}

The latest research about client loyalty in hotel industry commonly use some determinant factors such as satisfaction, involvement, perceived value, switching cost, quality and the other related factors $[5,18]$. In line with researchers that commonly use bivariate analysis approach, most of the studies measure customer loyalty using conative loyalty [2, 19]. Those studies conclude that creating loyal customer can be developed through providing a high service quality and a high perceived service value that can satisfy customer need. Back [20] is the only identified researcher who uses three elements of attitude, there are a cognitive aspect, affective aspect, and conative aspect, to measure customer loyalty in the star-rating hotel.

A comprehensive study that tests the association between behavioral intention, quality of service, satisfaction, image and value of service in Taiwan hotel industry has been conducted by Clemens and colleagues [21]. Their study aims to get an exhaustive consideration of "loyalty battery". The results of their research emphasizes the important of satisfaction toward the service, service value, quality of service, and image for deciding customer intention to being loyal in the future. Other scholars [21] also report how service quality hierarchically influences customer intention to behave either directly or indirectly toward the accommodation service provider. Those studies specifically discuss behavioral intention (conative loyalty), therefore, in essence, they only focus on conative aspect of attitudinal loyalty. The other research on loyalty in the hotel industry is conducted by other scholars in star-rating hotels. Even though those researchers be able to elaborate all of the determinant factors for loyalty behavior, the effect of those factors cannot be generalized in budget accommodation. Thus, it is important that this current study focuses on satisfaction and loyalty as a sustainable strategy for non-star rating hotel.

\section{Research method}

The measurement of variable constructs applied is referred to the recent literature. Attitudinal loyalty is defined as customer dispositional commitment levels towards a hotel. Four item that adopted from past studies [20][16] used for measuring this construct. While service quality is defined as a complete evaluation of all the service that received by hotel customer during their staying. This variable is measured by 11 items adapted from past studies [16]. Those items adopted as they are consistent with SERVQUAL dimensions; there are tangible, reliability, assurance, empathy, and responsiveness. Customer satisfaction is measured by two factors that adapted other studies [12, 22]. The last factor, customer perceived service value is gauged by two indicators [12]. The population of this research is consisted of all guests who stayed in accommodation service providers (non-star hotel) in five main tourism destinations in West Java; there are Cianjur, Cirebon, Bandung, Sukabumi, and Ciamis. As it is almost impossible to apply random sampling, this study uses convenience sampling to select the respondents. This research is intended to assess satisfaction and loyalty as the basis for developing sustainable in non-star hotel service industry. The skewness and kurtosis tests show that the data distribution is not normal. Therefore, the estimation model of the relationship between variables was conducted by employing logistics regression method. Prior to testing the relationships, the loyalty data was transformed into binary data, loyal and not loyal.

\section{Data analysis and result}

The respondents are 298 domestic tourists collected from a various region in West Java. As there are four variables used (loyalty, satisfaction, quality, and value), the number of the data is adequate for using multiple regression to analyze the data [22]. The result of 
descriptive statistics test towards four tested variables is shown in Table 1. Refer to this analysis result, this finding notes that tourist perception of quality, value, level of satisfaction and loyalty toward the non-star hotels service is relatively low. This result is indicated by the average score in all variables less than 4 . This finding suggests that domestic tourists towards non-hotel or budget-accommodation service provider are not loyal. In other words, the domestic tourists do not consider that the accommodation they stay as their first choice when coming again to the same destination.

To identify factors that lead customers loyal toward non-star hotel services, the analysis was conducted using logistics regression analysis. The result shows that the impact of service value and service quality individually towards customer satisfaction is shown in Table 2. Wald-Test is used for this testing, showing that service quality significantly affects customer satisfaction $(\mathrm{p}<0.01)$. In addition, service value does not significantly affect customer satisfaction since its significance level at $p>0.05$. The odd ratio (Exp B) value of service quality is very high, 100,755. This suggests that service quality will 100 times affect customer satisfaction.

Wald-Test result is depicted in Table 3 informs the effect of the quality of service and satisfaction individually on perceived service value. This test shows that quality significantly influences service value with significance level at $p<0.05$. While customer satisfaction does not significantly affect service value because its significance level is at $\mathrm{p}>0.05$. The next Wald-Test was conducted to explain the impact of quality, satisfaction, value individually towards customer loyalty. The result of this assessment is depicted in Table 4 . Based on the test result, all of those variables significantly affect customer loyalty with significance level at $0.009,0.000$, and 0.003 respectively. Further, service quality has the highest value of odd ration (Exp B) compared to other variables.

The result of correlation test shows that quality satisfaction, value, and customer loyalty are correlated and affected each other. This finding is supported by the result of logistics regression. Logistics regression shows that the higher the service quality, the higher the level of customer satisfaction. In the logistics regression test for customer satisfaction variable, the significance of service quality is at $p<0.01$, meaning that service quality is a key element to improve satisfaction. This result indicates that in case of non-star hotels, the quality of service, perceived service value, and satisfaction are imperative factors in determining customer loyalty behavior.

Table 1. Variable analysis based on the place where data collected.

\begin{tabular}{|l|c|c|c|c|c|c|c|c|}
\hline \multirow{2}{*}{ City } & \multicolumn{2}{|c|}{ Service Quality } & \multicolumn{2}{c|}{ Service Value } & \multicolumn{2}{c|}{$\begin{array}{c}\text { Customer } \\
\text { Satisfaction }\end{array}$} & \multicolumn{2}{c|}{ Customer Loyalty } \\
\cline { 2 - 9 } & Mean & $\begin{array}{c}\text { Std. } \\
\text { Dev }\end{array}$ & Mean & $\begin{array}{c}\text { Std. } \\
\text { Dev }\end{array}$ & Mean & $\begin{array}{c}\text { Std. } \\
\text { Dev }\end{array}$ & Mean & $\begin{array}{c}\text { Std. } \\
\text { Dev }\end{array}$ \\
\hline Cianjur & 4,363 & 0,5940 & 4,180 & 0,8850 & 4,160 & 0,8597 & 4,423 & 0,6812 \\
\hline Cirebon & 3,209 & 0,4658 & 3,170 & 0,8841 & 3,112 & 0,6635 & 3,155 & 0,7871 \\
\hline Bandung & 3,448 & 0,6521 & 3,393 & 0,7432 & 3,186 & 0,9135 & 3,152 & 0,8217 \\
\hline Sukabumi & 3,652 & 0,5892 & 3,625 & 0,7033 & 3,385 & 0,6937 & 3,516 & 0,6602 \\
\hline Ciamis & 3,655 & 0,6462 & 3,500 & 0,7354 & 3,570 & 0,8452 & 3,447 & 0,7013 \\
\hline
\end{tabular}

Table 2. Variables in the equation customer satisfaction.

\begin{tabular}{|l|l|r|l|l|r|r|r|}
\hline \multicolumn{2}{|c|}{} & $\beta$ & S.E. & Wald & df & \multicolumn{1}{l|}{ Sig. } & $\operatorname{Exp}(\beta)$ \\
\hline \multirow{3}{*}{$\begin{array}{l}\text { Step } \\
1\end{array}$} & & & & & & 100,755 \\
\cline { 2 - 8 } & Value & 0,308 & 0,347 & 0,785 & 1 &, 376 & 1,360 \\
\cline { 2 - 8 } & $\begin{array}{l}\text { Constan } \\
\mathrm{t}\end{array}$ & $-15,512$ & 2,645 & 34,391 & 1 &, 000 &, 000 \\
\hline
\end{tabular}


Table 3. Variables in the equation service value.

\begin{tabular}{|l|l|l|l|l|l|l|l|}
\hline \multicolumn{2}{|c|}{} & $\beta$ & S.E. & Wald & df & Sig. & $\operatorname{Exp}(\beta)$ \\
\hline \multirow{2}{*}{$\begin{array}{l}\text { Step } \\
1\end{array}$} & & & & & & 11,237 \\
\cline { 2 - 8 } & Satisfaction &,- 191 &, 393 &, 238 & 1 &, 626 &, 826 \\
\cline { 2 - 7 } & Constant & $-6,050$ & 1,364 & 19,683 & 1 &, 000 &, 002 \\
\hline \multicolumn{2}{|l|}{ a. Variable(s) entered on step 1: Servqual, Satisfaction. } \\
\hline
\end{tabular}

Table 4. Variables in the equation customer loyalty.

\begin{tabular}{|l|l|l|l|l|l|l|l|}
\hline \multicolumn{2}{|c|}{} & $\beta$ & S.E. & Wald & df & Sig. & $\operatorname{Exp}(\beta)$ \\
\hline \multirow{3}{*}{$\begin{array}{l}\text { Step } \\
1\end{array}$} & & & & & & & 9,008 \\
\cline { 2 - 8 } & Satisfaction & 1,166 &, 397 & 8,620 & 1 &, 003 & 3,209 \\
\cline { 2 - 8 } & Value &, 935 &, 356 & 6,911 & 1 &, 009 & 2,548 \\
\cline { 2 - 7 } & Constant & $-13,225$ & 2,086 & 40,197 & 1 &, 000 &, 000 \\
\hline
\end{tabular}

\section{Conclusion, implication, and future research}

The contribution of this research is to extend our understanding on customer loyalty model especially in non-star hotel accommodation service and identifying the driving factors of customer loyalty with its three determinant factors: the quality of the service, service value, and satisfaction level. As both satisfaction and loyalty are the basic requirements of sustaining any business organization, including in accommodation service industry, this research contributes in highlighting the pivotal role of delivering a high quality of service and creating a high perceived service value as a strategy to sustain any non-star hotel service provider. From a theoretical perspective, this study contributes to extending our understanding that delivering a quality service, creating a high service value that can satisfy customer are imperative factors in creating guest loyalty. As limited studies have been conducted in non-star hotel or budget accommodation context, thus, this paper not only confirms the result of previous studies in star hotels but it also offers a new empirical evidence in the context of budget accommodation services.

From a managerial perspective, this research provides non-star hotel service managers with the basis for developing, flourishing, and sustaining their accommodation business, especially in this Industry 4.0 era. This research reveals that the domestic tourist did not consider that accommodation service provider where they stay as their first choice when revisiting to the destination. The hotel service that they received does not make them want to choose the same accommodation or recommend it to their friends or relatives. To develop guest loyalty (revisit and recommend the hotel), non-star hotel managers should be aware the importance of delivering a high service quality and providing a high service value. In particular, this research recommends that the accommodation services should be improved with stressing on employee service skill and professionalism that can make guests trust to the hotel. Besides employee service skill and appearance, the hotel appearance including neatness, interior and exterior design, and hotel facilities that meet customer needs have to be the attention of hotel managers.

This study has several drawbacks, although it does contribute in terms of theoretical and managerial application. The first drawback related to the data gathered from a few tourist destinations in West Java province. The limited collection of the data from a few tourist destinations causes that the finding of this study cannot be generalized to other tourist destinations. The future study could replicate this research in other tourist location as the different location has different guest behavior due to the cultural differences. The second drawback is related to the model tested with including quality, value, and satisfaction as the 
loyalty drivers. Besides these factors, many more variables that potentially influence guest loyalty such as brand image, destination image, and customer motivation [2,5]. Including these variables will increase the predictability of loyalty model in non-star hotel industry.

\section{References}

1. C. Jesus and M. Franco, "Cooperation networks in tourism: A study of hotels and rural tourism establishments in an inland region of Portugal," Journal of Hospitality and Tourism Management, vol. 29, pp. 165-175, 12 (2016)

2. J. Kandampully, T. Zhang, and E. Jaakkola, "Customer experience management in hospitality: A literature synthesis, new understanding and research agenda," International Journal of Contemporary Hospitality Management, vol. 30, pp. 2156, (2018)

3. C. F. Lin and Y. Y. Lin, "Internal and external marketing for exotic restaurant," Journal of Foodservice Business Research, vol. 13, pp. 193-216, (2010)

4. D. Suhartanto, D. Dean, R. Nansuri, and N. N. Triyuni, "The link between tourism involvement and service performance: Evidence from frontline retail employees," Journal of Business Research, vol. 83, pp. 130-137, (2018)

5. A. S. Hussein, R. D. V. Hapsari, and I. Yulianti, "Experience quality and hotel boutique customer loyalty: Mediating role of hotel image and perceived value," Journal of Quality Assurance in Hospitality \& Tourism, pp. 1-18, (2018).

6. BPS. Jumlah tamu asing pada hotel non-bintang menurut provinsi tahun 20032010

[Online].

Available: http://www.bps.go.id/tab_sub/view.php?tabel=1\&daftar=1\&id_subyek=16\&notab $=6$

7. R. Hapsari, M. D. Clemes, and D. Dean, "The impact of service quality, customer engagement and selected marketing constructs on airline passenger loyalty," International Journal of Quality and Service Sciences, vol. 9, pp. 21-40, (2017)

8. R. L. Oliver, "Whence consumer loyalty?," Journal of Marketing, vol. 63, pp. 3344, (1999)

9. D. Suhartanto, "The role of store coopetition and attractiveness on the performance of tourism destination and its retail stores," International Journal of Tourism Policy, vol. 7, pp. 151-165, (2017)

10. A. H. Eagly and S. Chaiken, "The advantages of an inclusive definition of attitude," Social Cognition, vol. 25, pp. 582-589, (2007).

11. D. Suhartanto, Ruhadi, and N. Triyuni, "Tourist loyalty towards shopping destination: The role of shopping satisfaction and destination image," European Journal of Tourism Research vol. 13, pp. 84-102, (2016).

12. B. Chitty, S. Ward, and C. Chua, "An application of the ECSI model as a predictor of satisfaction and loyalty for backpacker hostels," Marketing Intelligence \& Planning, vol. 25, pp. 563-580, (2007).

13. C. Lovelock and J. Wirtz, Service Marketing - people, technology, strategy, 6 ed. Upper Saddle River: Pearson Prentice Hall, (2007).

14. V. A. Zeithaml, L. L. Berry, and A. Parasuraman, "The bahavioral consequences of service quality," Journal of Marketing, vol. 60, pp. 31-46, (1996)

15. J. J. Cronin, M. K. Brady, and T. M. Hult, "Assessing the effects of quality, value, and customer satisfaction on consumer behavioral intentions in service environments," Journal of Retailing, vol. 76, pp. 193-218, (2000)

16. X. Han, R. J. Kwortnik, and C. Wang, "Service loyalty: An integrative model and examination across service contexts," Journal of Service Research, vol. 11, pp. 2242, (2008). 
17. D. Suhartanto, "Tourist satisfaction with souvenir shopping: evidence from Indonesian domestic tourists," Current Issues in Tourism, vol. 21, pp. 663-679, (2018)

18. A. S. Lo, H. H. Im, Y. Chen, and H. Qu, "Building brand relationship quality among hotel loyalty program members," International Journal of Contemporary Hospitality Management, vol. 29, pp. 458-488, (2017).

19. Y. Ekinci, G. R. Massey, and P. L. Dawes, "An extended model of the antecedents and consequences of consumer satisfaction for hospitality services," European Journal of Marketing, vol. 42, pp. 35-68, (2008)

20. K. Back, "The effect of image congruence on customers brand loyalty in the upper middle-classs hotel industry," Journal of Hospitality \& Tourism Research, vol. 29, pp. 448-467, (2005)

21. M. D. Clemes, J. H. Wu, B. D. Hu, and C. Gan, "An empirical study of behavioral intentions in the Taiwan hotel industry," Innovative Marketing, vol. 5, pp. 364390, (2009)

22. D. Suhartanto, D. Dean, A. Sosianika, and T. Suhaeni, "Food souvenirs and their influence on tourist satisfaction and behavioural intentions," European Journal of Tourism Research, vol. 18, pp. 133-145, (2018) 